\title{
Low-Cost Versus Frugal Innovation Building Blocks \& the Fundamentals of Jugaad Business Modeling
}

\begin{abstract}
Jamal Boukouray*
In this paper, we seek to present the first holistic and frugal business model ever designed to bridge the digital divide in Greenfield Africa. Based on an extensive implication in the Connecting Africa and OLPC Projects, Airtel Telecom Group (a Canadian company) partners decided to go one step further in their quest to revamp state owned telcos and postal service providers who were on the brink of collapse.

Unlike low-cost models developed by well-known heavyweights like SFR, Ryanair, Blue Jet, Easyjet, Walmart, etc., a frugal and sustainable business model like the one discussed in this paper has a lot more to do with Jugaad Innovation frameworks which led to many affordable and responsible breakthroughs in healthcare, education, housing, broadband, transportation, alternative energies, etc.; therefore, our main goal is to (a) distinguish between frugal and costkilling models, (b) explain the characteristics of jugaad-based framework and philosophy versus revenue-driven business models, (c) explain the importance of sustainable and organic business models in developing markets versus imported plug \& play recipes. At last, we will describe the fundamental building blocks of juggad innovation business models and their impact on growth perspectives for MNCs and entrepreneurs willing to break into greenfield markets.
\end{abstract}

Keywords: jugaad innovation, sustainability, frugal innovation, low cost business model, micro-finance.

Submitted: 25.08.16 | Accepted: 25.10.16

\section{Podstawy innowacji niskokosztowych w porównaniu z innowacjami oszczędnościowymi oraz fundamenty tworzenia modeli biznesowych typu jugaad}

Celem artykutu jest przedstawienie pierwszego w historii holistycznego i oszczędnościowego modelu biznesowego ukierunkowanego na zmniejszenie przepaści cyfrowej wśród najuboższej ludności Afryki. Bazując na szerokim udziale w projektach Connecting Africa i OLPC, partnerzy grupy Airtel Telecom (spótki kanadyjskiej) postanowili pójść dalej w dążeniu do reorganizacji państwowych operatorów telekomunikacyjnych i dostawców ustug pocztowych, którzy znajdowali się na skraju bankructwa.

Wodróżnieniu od modeli niskokosztowych opracowanych przez znane potężne firmy, np. SFR, Ryanair, Blue Jet, Easyjet, Walmart itd., oszczędnościowy i zrównoważony model biznesowy, taki

Jamal Boukouray, PhD - Université Internationale de Casablanca.

Correspondence address: Université Internationale de Casablanca, Casa Green Town, Route Provinciale, 3020, Casablanca-BP50169 Casa Ghandi, Maroc, e-mail: Jamal.boukouray@uic.ac.ma. 
jak ten omawiany $w$ artykule, ma wiele wspólnego z innowacjami typu jugaad, które doprowadzity do powstania wielu przystępnych cenowo i odpowiedzialnych przełomowych rozwiazań $w$ dziedzinie opieki zdrowotnej, edukacji, mieszkalnictwa, dostępu szerokopasmowego, transportu, alternatywnych źródet energii itd. Gtównym celem autora artykułu jest: (a) dokonanie rozróżnienia pomiędzy modelami oszczędnościowymi a modelami radykalnej optymalizacji kosztów, (b) przedstawienie charakterystyki zasad oraz filozofii opartych na pojęciu jugaad $w$ porównaniu z modelami biznesowymi opartymi na dochodach, (c) objaśnienie znaczenia zrównoważonych $i$ organicznych modeli biznesowych na rynkach rozwijajacych się w porównaniu z zaimportowanymi gotowymi rozwiazaniami. Ponadto opisano podstawowe elementy modeli biznesowych opartych na innowacjach typu juggad oraz ich wptyw na perspektywy rozwoju przedsiębiorstw wielonarodowych i przedsiębiorców sktonnych do wejścia na nowe rynki.

Słowa kluczowe: innowacje typu jugaad, zrównoważony rozwój, oszczędne innowacje, niskokosztowy model biznesowy, mikrofinanse.

Nadesłany: 25.08.16 | Zaakceptowany do druku: 25.10.16

JEL: O339, O350, O55, Q01

\section{Introduction}

Many companies and investors alike are lured by the untapped opportunities existing in Greenfield Africa and the potential profits that could emanate from selling cheap goods, low-end equipment, refurbished and sometimes obsolete or outdated goods to low-income consumers in frontier or emerging markets; but very few MNCs think about developing made-to-measure business models to suit the needs of informal markets or dynamics.

Airtel Telcom Group (ATG or Airtel herewithin) and its key strategic allies from Canada (IT \& wireless equipment manufacturers) have decided to go where others fear to tread. The company started a pilot project with a couple of goals in mind: (a) to bridge the digital divide in SubSaharan Africa; and (b) to help incumbent operators (historical operators) to develop affordable IP solutions (VoIP, IPTV, data transfer) which could revamp the postcolonial infrastructures and the nearly extinct operators in the targeted region.

Therefore, the company chose WiMax ${ }^{1}$ based solutions and applications which the WIMAX FORUM promoted and praised as the most economical and easiest solution to deploy for wireless networks. Most of the pilot project was designed for rural or underdeveloped nations who wished to develop affordable wireless networks through low cost base stations and affordable CPE modules in the same spirit as the OLPC (One Laptop Per Child) initiative led by Negroponte in the early years after the Millennium 2000.

Whilst telecom operators offer mostly airtime and limited internet access and no computer equipment which might enable sub-Saharan households to connect to the internet, ATG bundles come with many preemptive solutions for very low income families considered by mainstream operators as non-addressable and unviable. The project promoters knew from the early beginning that affordability and ROI will be a major concern and a big challenge to reckon with. As a team of social innovation entrepreneurs, the small team decided to think differently from other telcos whose market capitalization and subscriptionbased business model are built on different economic tenets and principles.

Based on our extensive research and fieldwork which lasted more than two and a half years in Central Africa and market studies both on the ground, we came out with an end-to-end "Jugaad" inspired business plan; and eventually with the first frugal business model of its kind applied to broadband projects; and more particularly to what is known in French Africa as PTT (Postal, Telephone \& Telex). On the empirical side, the action research was meant to help historical carriers and postal service providers to deal with the pent-up demand for affordable access to broadband services at the lowest cost possible.

In this research paper and case study, we would like to share with our fellow pundits the inspirational journey of a group of 
Canadian entrepreneurs and telecom engineers who spent countless months trying to develop the first micro-economic and low-cost network of its kind to help bridge the digital divide in some of the poorest nations on the planet; but also to share some insights on managing social innovation entrepreneurship challenges in greenfield markets where growth opportunities are high but the risks to fail are far greater even for the most seasoned executives and investors due to the incredible amount of unpredictable obstacles and hurdles which international business developers come across; let alone working in cross-cultura environment and dealing with multiple layers of bureaucracy, partners, stakeholders and relentless winds of uncertainty. These are some of factors which led us to first examine how compatible mainstream business models practiced by major carriers are with local lifestyles and business environment in Greenfield Africa; second to examine the foundations of low-cost business practices; and at last, to adapt frugal thinking and philosophy to business modeling as an alternative and sustainable solution to commercially motivated business formulae.

From a more realistic perspective, the question that haunted all advocates of the "connecting the unconnected" project was how to develop a business model which could be both viable, affordable to most budgets and yet attractive enough to lure wary investors to one of the most stigmatized areas in the world. This was neither an easy matter, nor an easy task for the faint at heart. It is still is a major concern, though, as there are still many underdeveloped countries where internet penetration is far below expectations and world standards.

From the research perspective, this long and strenuous experiment helped us understand the limitations of trying to duplicate, imitate or implement plug and play business models imported from leading low-cost players. While low-cost business practices have been so successful in developing or emerging markets as a competitive practice full of catch and hook tactics to lure bargain hunters, jugaad mindset is rather a distinct philosophy. Whilst being cost-effective is a paramount building block in both business models (Osterwalder and Pigneur, 2010), the two frameworks are rather built on distinct fundamental ten- ets (or different philosophical principles); hence the importance of the business case that started as a quest to lower manufacturing costs of cheap personal computers to become a turn-key project where households would get refurbished computers and instant access to the most affordable broadband network including voice, video and data at a fraction of current broadband rates.

As a result, the research paper will focus on the great chasm which separates commercially motivated low-cost concepts versus jugaad-based models and, hopefully, lay down the foundations for a new framework. But before going any further, it is important to define the main concepts which will be addressed and utilized within this emerging field and area or research.

\section{What Are the Differences \\ Between Low-Cost and Jugaad?}

Even though, Jugaad ${ }^{2}$ philosophy and frugal innovation thinking have always existed throughout history and around the globe as illustrated through many success stories by many authors (Radjou, Prabhu and Ahuja, 2011), the concepts and frameworks are still murky, including the newly discussed concept of jugaad leadership (Boukouray, 2016), which we had the opportunity to argue, examine and debate in academic circles, workshops and scientific venues (PRME-CEEMAN Conference and ASBBMC in Riga, Latvia, 2016 and elsewhere (Entrepreneurship for the XXI Century, 2016).

The jugaad concept and success stories have gained traction in both academia and popular press. It has been used for the right or wrong reasons in many different disciplines, areas of practice, research, and projects but as an experimental, conceptual or formal business model, the terrain is still fertile for other explorers.

Had there been more space to present the overall business case, business plan, the rollout strategy and outcomes of the pilot, we would have been able to show step by step how frugal thinking unfolds at every nod, every tier and every phase from the negotiation stage of the spectrum license agreements and conditions up till the post pilot phase. Why?

Because, contrary to cost-killer models commonly practiced by savvy aircraft car- 
riers, frugal thinking is a systematic and systemic use of frugal thinking as a backbone; a sort of supporting thrust that keeps the interdependent sub-systems and core architectural plan grounded and connected to the needs of those who cannot fit into standard business models. If revamping the decayed infrastructures, facilities, towers, antennas, backhauls is a crucial constituent of jugaad's undeterred commitment to upcycling what is already there, having a frugal state of mind all along the process is the cement that holds the $\mathrm{BP}$ and BM together. All stakeholders, key players and partners must abide by the same tenets. As far as we remember, there was not one instance where frugality and sustainability were downgraded, obliterated or ignored during and after the conceptual phase of the first business drafts and plans. Every layer of the micro-economic business model is built around this cornerstone.

As such, we consider the jugaad business model as a holistic, organic and sustainable approach by which companies, social innovation entrepreneurs, artisans, craftsmen or cooperatives use the most basic resources to create social economic value out of adversity not just for those within their own perimeter but for the entire community.

Furthermore, opposite to industrialized, capital-intensive low-cost businesses, the jugaad business model is a systematic and synchronized approach meant to work around constraints, obstacles, shoestring budgets, restricted supplies (like the American embargo on Cuba); therefore, it is agile, inventive and adaptive. MNCs that are eager to break into informal markets (greenfield, developing or emerging markets for instance) could certainly benefit from reverse innovation thinking approaches (Govindarajan et al., 2012) to build homegrown strategies which certainly appeal to the local communities. Some of the best performing companies in Africa rely on ethnic marketing to capture the huge traffic that takes place in informal markets, souks and "neo flea markets" like Samsung, which has set-up eco-friendly showrooms in what looks like an open sky outlet in a flea market. If the business model happens to be mechanical like Osterwalder's (Osterwalder and Pigneur, 2010) canvas, it will most likely fail to capture the delicate nature of doing business in frontier markets where the most dynamic sector is the informal economy.
Airtel's business case is rather unique as it embeds other pre-emptive measures which became a competitive advantage.

What are the characteristics related to pre-emptive strategies?

According to David Aaker, a preemptive move "is an implementation of a strategy new to a business area that, because it is first, generates an asset or competency that competitors are unable to duplicate or counter. A sustainable first-mover advantage can result from technological leadership, preemption of assets, and/or customer switching costs" (Aaker, 1998).

Here is why Airtel's business approach and philosophy reflect the previous assumptions about jugaad business modeling:

a) Most mainstream telecom carriers do not target households with the lowest incomes and do not wish to get involved with hardware sales of refurbished personal computers to avoid warranty issues or unprecedented levels of returned merchandise. Companies like Maroc Telecom, MTN and Orange are mostly concentrated in urban areas whereas WiMax-based providers like Airtel have targeted rural communities outside the fiber optic loop;

b) The company targeted also state-owned postal service operators who have an extensive network of unconnected agencies;

c) By signing a joint-venture agreement with the historic incumbent based on jugaad thinking, Airtel managed to kill two birds with one stone:

1. Airtel managed to skip the telecom beauty contests and obtained the right to use the state-owned spectrum license free of charge, including other exemptions such as the tax and excise on imported hardware, software and telecom gears due to the social economic nature of the project;

2. By obtaining the right to leverage and use the state-owned infrastructures (towers, antennas, shelters, building, technicians), the time-to-market became short so as the amortization period.

The 50 MHZ spectrum license represents a huge saving as it costs several millions of dollars. On a normal base, mainstream telcos have to go through nasty bids and tenders where being the highest or the lowest bidder does not necessarily guar- 
antee a happy ending. In fact, many telcos engaged in a shopping spree of spectrum licenses in greenfield markets not only to secure potential market shares but also to hold them as speculative assets for future sales or mergers, etc.

In fine, Airtel's frugal and sustainable approach is very distinct from other telcos that pretend to offer affordable bundles as mainstream telecom carriers do not target households with the lowest incomes, namely those who live in remote or rural areas and do not wish to get involved with hardware sales of refurbished personal computers. Companies like Maroc Telecom, MTN and Orange are mostly concentrated in urban areas where they can target upper or middle class income households or small, medium or large corporation. On the other hand, Airtel is mostly concerned about the big chunk of consumers who figure at the bottom of the pyramid.

In fact, Airtel's approach is very similar to how local entrepreneurs in informal economies and market start new businesses or projects:

Most frugal and jugaad entrepreneurs are used to recycling, upcycling whatever infrastructures, tools, parts or products available to deal with scarcity, underfunding, affordability issues in the exact same way the Canadian entrepreneurs tried to leverage their strategic alliances with historical operators whose broadband and postal equipments, infrastructures and supplies were in a decayed stage or of very poor quality.

Whether upcycling refurbished computers donated by Canadian households or companies or fixing decayed towers, shelters, antennas, Airtel's approach is way more frugal in its DNA when compared to mainstream telecom operators who do not care about underserved populations.

\section{Conclusion}

If we take the ripple effect and the numerous advantages related to frugal thinking versus low-cost pricing and practices, jugaad as a comprehensive economic model is far more efficient when it comes to developing a pre-emptive edge over the competition. Additionally, when you combine it with strategic market share development, marketing, and mass-deployment, jugaad has the capacity of accelerating the go-to-market and time-to-market refurbished, revamped and improved solution at a fraction of what mainstream players could charge for similar services, products, equipment, etc. In our case study, the experiment and pilot project combining frugal thinking as a navigation system, as a threshold and as a sustainability index is far more powerful than thinking in discount terms. Making the cheapest computer as initially intended by Negroponte (OLPLC advocates), $\mathrm{XO}-01^{3}$, Asus, etc. is unlikely to solve digital literacy issues in sub-developed nations as it is a linear solution to a non-linear problem 4 .

In sum, we might say that jugaad business models are a set of inbound and outbound mechanisms which entitle community sensitive entrepreneurs to strive, against the odds, to deliver chain value-added solutions in hostile political, economic, social, technological, educational, legal or even circumstantial environments. Whether they are jump starters, kick starters or wellestablished firms, jugaad friendly entrepreneurs must bear in mind that having a frugal mindset is not necessarily about cutting the fat, developing the cheapest product, or the least expensive device, or about outselling the competition through cut-throat hat tricks to bargain-seeking consumers; it is about upcycling the existent potential, converting adverse conditions and hurdles into a resilient pre-emptive advantage and eventually into a source of intercultural differentiation from mainstream or commercial price motivated vendors who built a reputation like Walmart on being the most aggressive player when it comes to staging price wars, blowout sales or attracting rebate zealots on a yearly basis.

Last but not least, it is important to understand that doing business in SubSaharan Africa not only requires a deep understanding of cross-cultural dimensions, diversity and geopolitical challenges, it also requires a great deal of intercultural intelligence when it comes to dealing with informal markets and the way of life in greenfield Africa. Therefore, the business building blocks cannot be reduced to a kit set of color coordinated post-its on 9 inches building blocks (Osterwalder and Pigneur 2010), there are various factors of differentiation and parameters which must be taken into account when it comes to implementing business models outside the well-known 
clusters, economic zones or territories. In Airtel's case situation, we have taken into consideration several frameworks including micro-finance for the micro-economic component in order to foster small franchise ownership for low income investors, computer acquisition for low income households, social economic responsibility to make sure that each stakeholder, business partner in the joint-venture agreement abides by the same principles. The stakeholders and the staff assigned to the project must share the same vision, apply their frugal skills at every step of the way in a systemic fashion; in other words, the structural foundation of any jugaad-based business model is a multilayered project where the sub-systems of the complexus are interconnected and interwoven in the same fabric from the onset stage till the post-deployment phase.

This telecom project in a frontier market is a typical illustration of how inadequate plug and play business models might be when it comes to expanding the business overseas, namely in informal markets where market segmentation criteria, social stratification parameters, income bracket grids are less relevant than the ethno-cultural variables such as the local customs, family structures, ethnic status, tribal values, power distance, cultural dimensions identified and largely used in cross-cultural studies ${ }^{11}$. Unless we take into account the peculiar nature of the local environment, informal channels of buying and selling, ancestral values, ethnic structures and colonial heritage for instance, the plug and play business model will not last more than "botox injections".

\section{Endnotes}

1 WiMax stands for Worldwide Interoperability for Microwave Access, which is a family of wireless communication standards based on the IEEE 802.16

2 Jugaad in a Hindi word which stands for clever improvisation. Based on various articles and literature reviews on the topic, jugaad is usually associated with frugal innovation thinking and with the creation of cheap and affordable products and solutions to suit the needs of those at the bottom of the pyramid. It is also known as "reverse innovation". In a special report by The Economist in 2011, frugal innovation is simply defined as "taking the needs of poor consumers as a starting point and working backwards; creating frugal products and services that are cheap and easy to use and serving the needs". Available at: http://www.economist.com/node/21551028/ print. The Economist, 2011. Special Report on Innovation in Emerging Markets. The Economist, 84(6), p. 16.

3 The XO-1, previously known as the $\$ 100$ Laptop, Children's Machine, and 2B1, was supposed to be an inexpensive subnotebook computer intended to be distributed to children in developing countries around the world, to provide them with access to knowledge, and opportunities to "explore, experiment and express themselves". The laptop was developed by the One Laptop per Child (OLPC) non-profit, organization and manufactured by Quanta Computer. The subnotebooks were designed with the intention to be sold to government-education systems which then gave each primary school child their own laptop. Pricing was set to start at \$188 in 2006, with a stated goal to reach the $\$ 100$ mark in 2008 and the 50-dollar mark by 2010. When offered for sale in the Give One, Get One campaigns of Q4 2006 and Q4 2007, the laptop was sold at \$199.

4 Problem solving according to McKinsey's famous approach: the problem is not always the problem; don't reinvent the wheel; every client is unique (no cookie cutter solutions); don't make the facts fit your solution; make sure your solution fits your client; sometimes let the solution come to you; no problem is too tough to solve, etc. http://www.projectnavigator.com/ downloads/mckinsey_approach.pdf.

\section{References}

\section{Business Model Frameworks}

Aaker, D. (1998). Strategic Market Management, University of California, Berkeley, John Wiley \& Sons.

Augier M. and Teece, D.J. (2006). Understanding complex organization: The role of know-how, internal structure, and human behavior in the evolution of capabilities. Industrial and Corporate Change, 15(2), 395-416.

Boukouray, J. (2016). How to turn frugal thinking into a sustainable business model and thriving organizational culture. Stanford Social Innovation Review, February.

Chesbrough, H. and Rosenbloom, R.S. (2002). The role of business models in capturing value from innovation: Evidence from Xerox Corporation's technology spin-off companies. Industrial and Corporate Change, 11(3), 529-555.

Christensen, C. and Johnson, M. (2009). What are business models, and how are they built? Harvard Business School Note 9-610-019.

Entrepreneurship for the XXI Century. Images and Perspectives (2016). International Scientific Conference, Centre for Entrepreneurship, Faculty of Management, University of Warsaw, November. 
Eyring, M.J., Johnson, M.W. and Nair, H. (2011). New business models in emerging markets. Harvard Business Review, 89(1/2), 88-95.

Lecoq, X., Demil, B. and Warnier, V. (2006). Le Business Model, un Outil d'Analyse Stratégique. L'Expansion Management Review, 123, 50-59.

McGrath, R.G. and Macmillan, I.C. (2005). Market busters: 40 strategic moves that drive exceptional business growth. Harvard Business School Press.

Markides, C. (2008). Game-changing strategies: How to create new market space in established industries by breaking the rules. Jossey-Bass.

Mayer, K.J. and Teece, D.J. (2008). Unpacking strategic alliances: The structure and purpose of alliance versus supplier relationships. Journal of Economic Behavior and Organization, 66(1), 106-27.

Osterwalder, A. and Pigneur, Y. (2010). Business model generation: A Handbook for visionaries, change makers and challengers. John Wiley \& Sons.

Teece, D.J. (2010). Technological innovation and the theory of the firm. In: B.H. Hall and N. Rosenberg (eds), Handbook of the Economics of Innovation, Chapter 16 (pp. 681-709). Amsterdam, Holland: North Holland.

Teece, D.J. (2009). Business model, business strategy, and innovation. Long Range Planning, 43(2010), 172-194.

Teece, D.J. (2005). Technology and technology transfer: Mansfieldian inspirations and subsequent developments. Journal of Technology Transfer, 30(1/2), 17-33.

Yip, G.S. (2004). Using strategy to change your business model. Business Strategy Review, 15(2), Summer.

Jugaad \& Frugal Innovation in Developing \& Emerging Markets

Ahlstrom, D. (2010). Innovation and growth : How business contributes to society. Academy of Management Perspectives (August), 10-23.

Chandra, M. and Neelankavil, J.P. (2008). Product development and innovation for developing countries: Potential and challenges. Journal of Manage ment Development, 27(10), 1017-1025.

Deloitte Touche Tohmatsu. (2006). Laboratories of innovation: Leveraging emerging markets, 1-6. Retrieved from: http://www.deloitte.com/assets/ DcomAlbania/Local\%20Assets/Documents/dtt manufacturing_laboratories_of_innovation(1).pdf.
Govindarajan, V. and Ramamurti, R. (2011) Reverse innovation, emerging markets, and global strategy. Global Strategy Journal, 1(3-4), 191-205.

Govindarajan, V. and Trimble, C. (2009). How GE is disrupting itself. Harvard Business Review (October), 56-66.

Govindarajan, V., Trimble, C. and Nooyi, I.K. (2012). Reverse innovation: Create far from home, win everywhere. Harvard Business Press.

Krishnan, R.T. (2010). From Jugaad to systematic innovation: The challenge for India. Utpreraka Foundation.

Köse, A. and Prasad, E.S. (2010). Emerging markets come of age. Finance \& Development, November, 7-10. Brookings Institution Press.

Navi, R., Prabhu, J. and Ahuja, S. (2012). Jugaad innovation: Think frugal, be flexible, generate breakthrough growth.

Osterwalder, A. and Pigneur, Y. (2010). Business model generation : A Handbook for visionaries, game changers, and challengers. Wiley \& Sons.

Pacek, N. and Thorniley, D. (2004). Emerging markets: Lessons for business success and the outlook for different markets. John Wiley \& Sons.

Prahalad, C.K. (2009). Bottom of the pyramid as a source of breakthrough innovations. Journal of Product Innovation Management, 29(1)

Prahalad, C.K. (2005). The fortune at the bottom of the pyramid: Eradicating poverty through profits. FT Press.

Prahalad, C.K. (2006). The innovation sandbox. Strategy + Business, 44. Retrieved from: http://www. strategy-business.com/article/06306.

Prahalad, C.K and Mashelkar, R. (2010). Innovation's holy grail. Harvard Business Review, 88(7/8), 132-141.

Radjou, N., Prabhu, J. and Ahuja, S. (2011). Jugaad Innovation: Think frugal, be flexible, generate breakthrough. Jossey-Bass.

Sangeeta, R. and Pradeep, K.R. (2011). Product innovation for the people's car in an emerging economy. Technovation, 31(5-6), 216-227.

Sehgal, V., Dehoff, K. and Panneer, G. (2010). The importance of frugal engineering. Strategy $+\mathrm{Busi}$ ness, Summer, 59(1-5).

The Economist (2012). Asian innovation: Fruga ideas are spreading from East to West. The Economist special report on innovation in emerging markets. The Economist, 84(6). Retrieved from: http://www.economist.com/node/21551028/print. 